\title{
セッケンの平衡含水量について
}

\author{
江崎平 八*大和田健次*野口駿*
}

\section{On the Equilibrium Water Content of Soap}

Heihachi Ezaki, Kenji ŌWada and Syun NoguchI

\section{1. 緒言}

脂肪酸アルカリ塩と水との系が示す平衡含水量飞つい ては, 古くから Stiepel ${ }^{1)}, \mathrm{Katz}^{2,3)}$ らの研究があり, さらとこれとセッケン諸相との関連, あるいは水和作用 (Hydration) 飞関する研究が J.W. McBain ら ${ }^{4)}$ ，W. W. Lee ${ }^{4), 5)}$ 特よび Ferguson ら ${ }^{6}$ とよって行なわれて いる。しかしこれらの研究の多くは単一脂肪酸のアルカ リ塩を対象とし，乙かも高温度でのものが多いためと， 一般のセッケン製造上用いられる室温付近の工学的デー タとして, 普遍的とは考光られない。そこでさき亿筆者 らはセッケンの乾燥を扱うために, 普通セッケンが室温 加5 $50^{\prime} \mathrm{C}$ に和いて示す平衡含水量の概略值を簡単な間 接法で求め, その際枠練りセッケン型と機械練りセッ ケン型とで異なる平衡含水量を示すととを認めたがて,

引き続き方法をいくぶし変更して普通セッケン括よび 二, 三の飽和招よび不飽和脂肪酸のナトリウム塩につい て実験を行なったのでそれらの結果を報告する。

\section{2. 試料の調製}

単一脂肪酸塩は単一脂肪酸を約 $20 \%$ カセイソーダ水 溶液でコン（痕）跡のアルカリ性になるまで中和し，放 冷後適宜風乾し, 約 1 ケ月間密七ン（栓）して保管し た。また普通セッケンは当工場で浴用セッケン用素地と しているるのをとのまま用いた。これらの脂肪酸の種類 招よび性状は次表のと招りである。

\section{3. 実験の方法亡装置}

さきと用いたデシケータ法を改めて Menzies-Collins 法帛を用いたがその概要はつぎのと捛りである。ガラス 管内にセッケン 3 5 g を細分して詰め, その上部に種 々の濃度の硫酸液を入れた細管を置き，外管を減圧下と 封じて（図-1）恒温りウ内に一定期間放置する。また硫 酸の濃度は既報》の平衡曲線から推定して試料とほぼ平 衡となるべき硫酸濃度よりすとし濃いものと, 薄いるの とを使用するようとした。平衡達する期間は従来の実 験から約 20〜30 日と推定され, さらに本実験と並行し て子備実験用に同種の試料を数個作り，一定期間ごとに

* 株式会社 丸見屋向島工場 (墨田区寺島町 8 の 104) Marumiya Co., Ltd.
表-1 試料の種類扢よび性状

\begin{tabular}{|c|c|c|c|c|}
\hline \multirow{2}{*}{ 種 } & \multicolumn{3}{|c|}{ 脂肪酸の性状 } & \\
\hline & $\operatorname{mp}\left({ }^{\circ} \mathrm{C}\right)$ & N.V. & I.V. & \\
\hline \multirow{4}{*}{$\begin{array}{l}\text { パルミチン酸 } \\
\text { ナトリウム } \\
\text { ラウリリン酸 } \\
\text { ナトリウム } \\
\text { オレイン酸 } \\
\text { ナトリウム } \\
\text { リ,ール酸 } \\
\text { ナトリウム }\end{array}$} & 62.0 & 218.6 & 0.6 & モクロウより分離 \\
\hline & 45.1 & 276.0 & 0 & $\begin{array}{l}\text { Eastman Kodak } \\
\text { 製 }\end{array}$ \\
\hline & - & 199.1 & 90.5 & Merk 製 \\
\hline & - & 199.2 & 151.2 & 市販品 \\
\hline 普通セッケン & 40.0 & 213.4 & 39.1 & 当工場製 \\
\hline
\end{tabular}

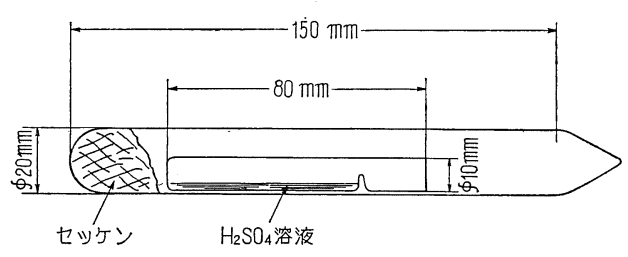

図-1 実 験 装 置

開封し約 30 日で圧とんど平衡と達したことを確認する ことができた。この結果, すべて実験はさらと余裕をと って 40 日後に開封し, 試料の含水量を常法によって測 定し, 硫酸濃度は重量変化から算出した。

\section{4. 実験の結果および考察}

得られた試料の 含水量 (以下乾量 基準で表わす) と これと平衡にある 硫酸の濃度加算 出した水蒸気圧と の関係を各試料炕 ついて図示すると

図-2,3,4,5,6 の ようとなる。また その一部を関係湿 度 $(\varphi)$ と平衡含水 量 $(E)$ との関係 と書きかえると図 ー7 となる。

a) 飽和脂肪酸 ナトリウム

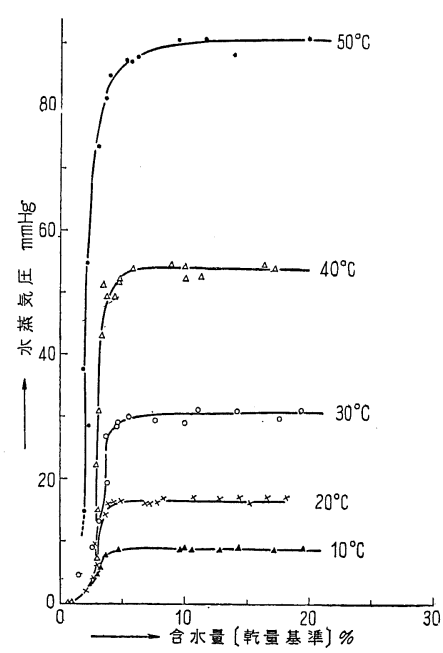

図-2 パルミチン酸ナトリウム の水蒸気圧 


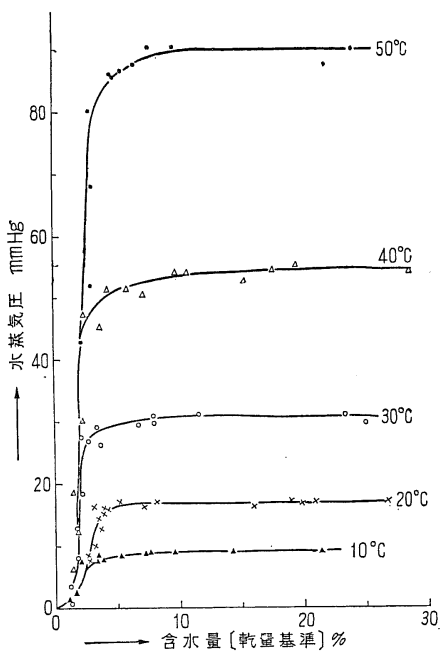

図-3 ラウリン酸ナトリウムの 水蒸気圧

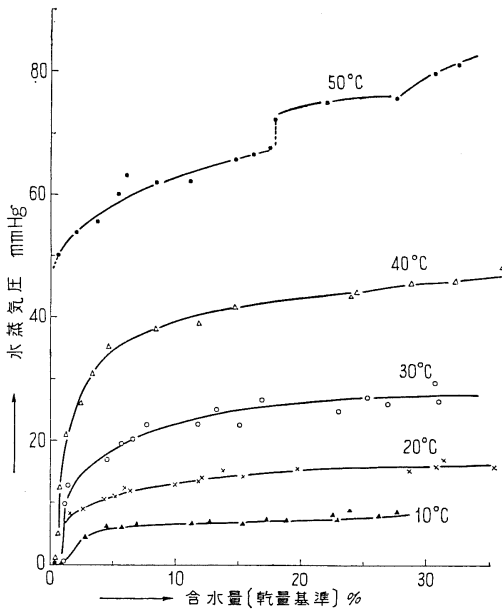

図-4 オレイン酸ナトリウムの 水蒸気圧

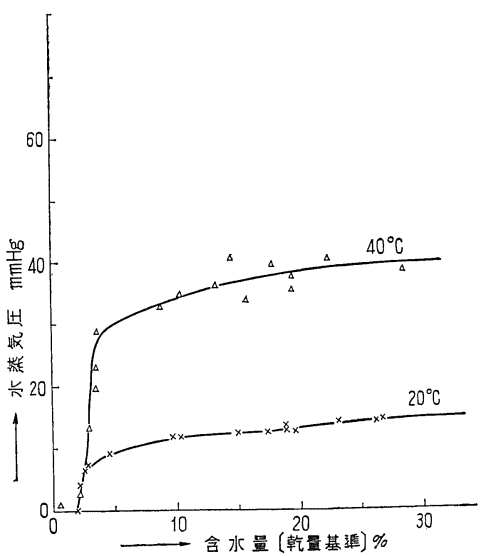

図-5 リノール酸ナトリウムの 水蒸気圧

パルミチン酸ナトリウム： $40^{\circ} \mathrm{C}$ 以下の場合にはつぎ の三段階に分けて考兵ることができる。まず，水蒸気圧 は含水量約 3\%まではほとんど0に近く,つぎに約 $3 \%$ になると急激に増加し，5～6\%でほぼ一定になる。こ れを関係湿度一平衡含水量の関係から見ると, やほり三 段階に分けられ，第一段階は $\varphi$ の増加に伴って $E$ が急 激にふ約 $3 \%$ まで続く。第二段階は $\varphi$ がほとんど 0 か ら約 $90 \%$ までで， $\varphi$ が増しても $E$ はほとんど増さな い過程である。第三段階は $\varphi$ が約 $90 \%$ 以上でわずかな $\varphi$ の増加で $E$ は急激な増加を示す。またこの $\varphi$ と $E$ との関係は 10〜 40ㄷ C゙は㤬とんど重なることがわかる。

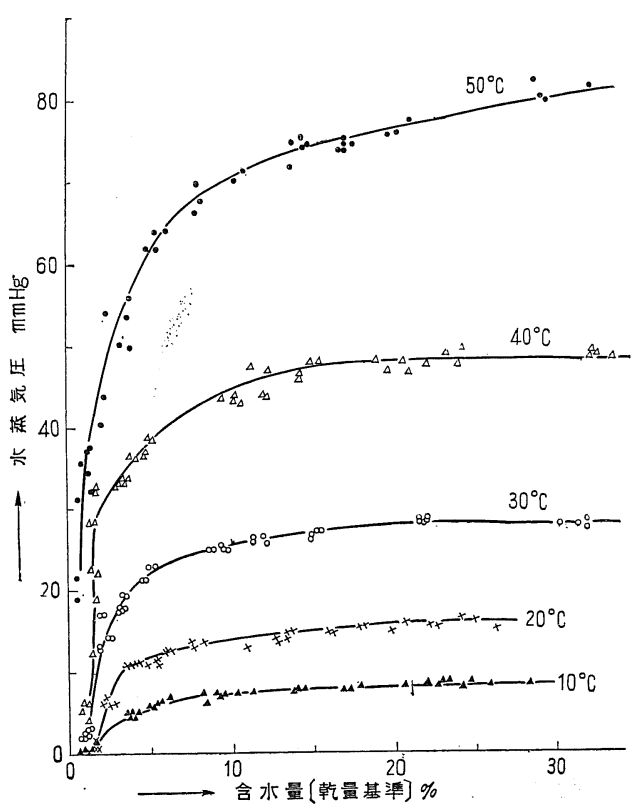

図-6 化粧セッケンの水蒸気压

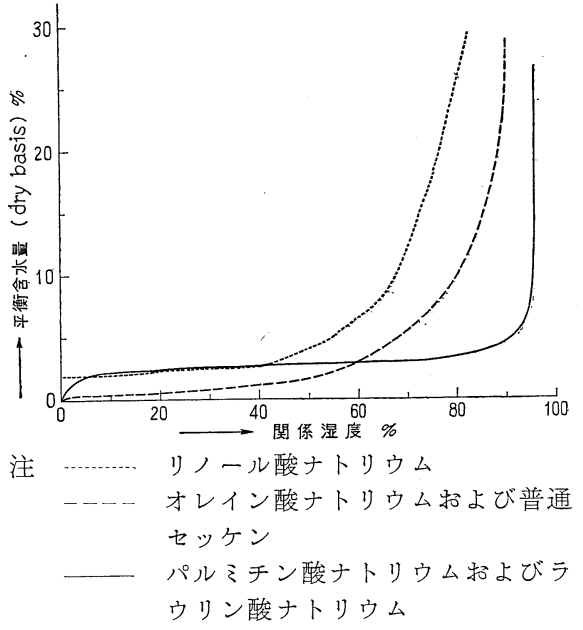

図-7 平衡含水量と関係湿度 $\left(20^{\circ} \mathrm{C}\right)$

一方, $50^{\circ} \mathrm{C}$ 飞括いては第一段と第二段との区別が明 瞭でなく, $\varphi=0 \sim 90 \%$ そ招いて $E$ は徐々に約 $4 \%$ 増 加してゆく。

以上のようにパルミチン酸ナトリウムは $40^{\circ} \mathrm{C}$ 以下の 温度に捈いては約 $3 \%$ 水がセッケン分子とかなり強い 結合を示し，このセッケンの hemi-hydrate が含水量 $3.24 \%$ (乾量基準) 飞相当することから，以ほ hemihydrate の存在を推定させるが $50^{\circ} \mathrm{C}$ 以上ではその存在 は不明確となる。な括 Ferguson ら ${ }^{6)}$ のパルミチン酸ナ トリウムに関する水蒸気圧の值 $\left(27^{\circ} \mathrm{C}\right)$ はほとんどこの 結果と一致している。

ラウリン酸ナトリウム：この場合はパルミチン酸ナト リウムの $50^{\circ} \mathrm{C}$ の場合と類似して招り，第一段之第二段 との区別は明瞭ではない。すなわち， $\varphi$ が 0 から約 $90 \%$ 
まで増加すると伴って $E$ は 0 から 3〜4\%まで徐々に 増加し， $\varphi>90 \%$ で $E$ は急激増加する。したがって この場合には明確な hemi-hydrate の存在は認めにく い。乙か乙全般的に水蒸気圧の值はパルミチン酸ナトリ ウムの場合とほとんど変らないことが認められる。

\section{b）不飽和脂肪酸ナトリウム}

オレイン酸ナトリウム: まず顕著なととは, その水蒸 気圧が $2 \sim 4 \%$ 以下の低含水量領域を除いては飽和酸塩 に比べて著しく低いことと， $40^{\circ} \mathrm{C}$ 以下と $50^{\circ} \mathrm{C}$ とでその 様子が著しく異なることである。すなわち $40^{\circ} \mathrm{C}$ 以下に 扣いては $\varphi$ が 0 から 60〜70\% まで変化すると， $E$ は 0 から 5 〜 6\%まで徐々に増加するが， $\varphi$ がこの領域を越 えると $E$ は急激に増加するようになる。そしてこの場 合 $E$ が急激忓上昇する $\varphi$ の值は温度上昇に伴ってすこ

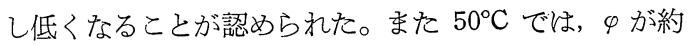
$50 \%$ までは $E$ がほとんど0でそれ以後は $\varphi$ の増加に伴 って $E$ は急激に増加するが，この状態は途中でバラッ キが多く, なんらかの構造上の変化を示するのと想像さ れるが詳しくは不明である。

リノール酸ナトリウム： $20^{\circ} \mathrm{C}$ 扰よび $40^{\circ} \mathrm{C}$ の場合飞つ いてのみ実験を行なったが，いずれの場合にるかなりの バラッキを示し, その水蒸気圧はオレイン酸ナトリウム より低く水との親和力がより強いことを示している。

\section{c) 浴用セッケン}

水蒸気圧の值は, $10^{\circ} \mathrm{C}$ 抢よび $20^{\circ} \mathrm{C}$ ではほとんどオレ イン酸ナトリウムと同じ值を持つが， $30^{\circ} \mathrm{C}$ 以上では飽 和酸塩と不飽和酸塩との中間的な值を示す。また $50^{\circ} \mathrm{C}$ の場合, $40^{\circ} \mathrm{C}$ 以下飞比べて $E$ が $\varphi=0 \sim 40 \%$ 飞拉いて かなり低く,水の結合状態が $40^{\circ} \mathrm{C}$ 以下の場合とはいくぶ 几異なることを予想させる。またこの結果は Ferguson ら 9)の常温に和ける結果とほぼ一致している。

つぎそここで以上の諸結果を McBain ら5) の行なっ たように等温吸着式

$$
\frac{x}{m}=k p^{1 / n}, x / m: 1 \mathrm{~g} \text { のセッケンの持つ水の重量 }
$$

$$
p: \text { 関係湿度 } \quad k: \text { 定数 }
$$

とよって $\log x / m$ と $\log p$ との関係をみると, 含水量 約 $2 \sim 4 \%$ 以上では $1 / n$ が明らかね 1 よりも大きくな り，単なる吸着のみによるものではないことが推定され る (McBain らはこれを capillary liquid の存在の根 拠としている)。

ここでカルボキシル基とついたアルカリ金属と水との 親和性は各脂肪酸塩で大きな差がないと考光られるが, 飽和脂肪酸塩は一般に結晶化しやすく微晶構造をとる が, 不飽和脂肪酸塩はとの立体構造から規則的配置はと りとくいと推定されるから, この構造の相違が水との親 和性飞大きく影響してくるものと考光られる。したがっ て既報のセッケンの機械的処理によってその水蒸気圧が 高くなるのもこれによって分子の配向性を高めて $\beta$ 型化 するため水の易動性が増大することによるるのとい えよう。ただし，機械的処理によるセッケン組成の $\beta$ 型 と, 単一脂肪酸ナトリウムの $\beta$ 型とが同じ構造あるいは 同じ水との結合状態にあるか否かはまだ疑問である。

(昭和 33 年 7 月 2 日受理)

$$
\text { 文献 }
$$

1) Stiepel, "Fette, Öle und Wachse" (Leipzig), p. 100 (1911)

2) Katz, Kolloidchem. Beih., 9, 102 (1918)

3) Katz, Zeitschr. deutsch. Öl-und Fett-Indus. trie, 44, 2555 (1924)

4) J.W. McBain et al., J. Am. Chem. Soc., 63, 1000 (1941); J.W. McBain, W.W. Lee, Oil \& Soap, 20, 17 (1943)

5) J.W. McBain, W.W. Lee, Ind. Eng. Chem., 35, 784 (1943)

6) R.H. Ferguson et al., J. Am. Chem. Soc., 69, 141 (1947)

7) 江崎 et al., 化学工学, 21, (10) 666 (1957)

8) Collins, Menzies, J. Phys. Chem., 40, 379 (1936)

9) R.H. Ferguson, R.D. Vold, Oil \& Soap, 15, 181 (1938)

\section{セッケンの乾燥機構について 荻野 圭 三* \\ Drying Mechanism of Paraffinic-Sodium Soap}

\section{Keizō OGINO}

\section{I. 緒言}

セッケンの乾燥については, 古くは W.K. Lewis ${ }^{1)}$ 物 よび T.K. Sherwood ${ }^{2)}$ の簡単な報告飞始末り， E.L.

* 旭電化工業株式会社 (東京都荒川区尾久町 9) Asahi Denkakogyo Co., Ltd.
Lederer $^{3)}$ や亀井 ${ }^{4}$ の代表的研究によって, セッケンは 内部拡散のきわめて困難な物質で乾燥を開始すれば直ち に減率第二段乾燥期に入るるのとされている。さらに最 近江崎 ${ }^{5)}$ はセッケンの結晶型の代表的二型 ${ }^{6)}(\omega$ と $\beta)$ をそれぞれ代表する枠練り括よび機械練りセッケンの平 衡含水量ならびねセッケン薄片の乾燥について報告し, 